\title{
PELATIHAN PENGGUNAAN APLIKASI QUIS ONLINE DALAM PEMBELAJARAN DARING
}

\section{TRAINING OF USING ONLINE QUIZ APPLICATIONS IN ONLINE LEARNING}

\author{
Taufik Hidayat*, Nia Rohayati, Suyono \\ Fakultas Keguruan dan Ilmu Pendidikan, Universitas Galuh \\ *Email: taufik@unigal.ac.id \\ (Diterima 05-05-2021; Disetujui 05-08-2021)
}

\begin{abstract}
ABSTRAK
Pembelajaran online menjadi isu hangat yang sering diangkat dalam diskusi pendidikan akhir-akhir ini. Pembelajaran online bukanlah hal yang mudah, apalagi jika guru belum terbiasa dengan perangkat teknologi. Berbagai survey yang dilakukan menunjukan bahwa mayoritas pelajar yang melaksanakan sistem belajar online menyatakan jenuh dan bosan dengan sistem belajar yang sedang dijalani. Guru sebagai ujung tombak dalam pendidikan dituntut lebih kreatif dan inovatif dalam pembelajaran online. Sebetulnya banyak media online yang dapat digunakan guru untuk menjadikan pembelajaran lebih interaktif. Salah satu caranyanya guru dapat menyisipkan game pembelajaran di kelas online. Namun, kurangnya pemahaman dan keterampilan tentang pembelajaran online menjadikan guru masih kesulitan melaksanakan pembelajaran online secara maksimal. Begitu juga degan guru-guru yang ada di wilayah Malangbong Garut pada berbagai jenjang pendidikan sebagai mitra dalam kegiatan pengabdian ini. Untuk memfasilitasi permasalahan tersebut, pelatihan terhadap guru-guru sangat diperlukan, terutama pelatihan pembelajaran daring yang interaktif. Tim pengabdi melaksanakan pelatihan penggunaan aplikasi quis online untuk meningkatkan interaksi dalam pembelajaran daring. Pelatihan dilaksanakan secara tatap muka dan tatap maya dengan jumlah peserta 60 orang. Materi pelatihan meliputi: 1) pentingnya pembelajaran daring yang menyenangkan; dan 2) pembuatan game interaktif (quis) dalam pembelajaran. Hasilnya, pelatihan disambut positif oleh guru-guru dari berbagai jenjang pendidikan.
\end{abstract}

Kata Kunci : pembelajaran daring, game interaktif, game pembelajaran

\section{ABSTRACT}

Online learning is a hot issue that is often raised in education discussions lately. Online learning is not an easy thing, especially if the teacher is not familiar with technological devices. Various surveys conducted show that the majority of students who implement the online learning system state that they are bored and bored with the learning system that is being undertaken. Teachers as the spearhead in education are required to be more creative and innovative in online learning. In fact, there are many online media that teachers can use to make learning more interactive. One way is that teachers can insert learning games in online classes. However, the lack of understanding and skills about online learning makes it difficult for teachers to carry out online learning optimally. Likewise, teachers in the Malangbong Garut area at various levels of education as partners in this service activity. To facilitate these problems, training for teachers is very much needed, especially interactive online learning training. The service team carried out training on the use of online quiz applications to increase interaction in online learning. The training was carried out face-to-face and virtual with a total of 60 participants. The training materials include: 1) the importance of fun online learning; and 2) making interactive games (quis) in learning. As a result, the training was received positively by teachers from various levels of education.

Keywords: online learning, interactive games, learning games

\section{PENDAHULUAN}

Saat ini Covid-19 menjadi pembicaraan yang hangat. Di belahan bumi manapun corona masih mendominasi ruang publik. Covid-19 adalah penyakit menular yang disebabkan oleh jenis coronavirus yang baru ditemukan. Walaupun lebih banyak menyerang ke lansia, virus ini 
sebenarnya bisa juga menyerang siapa saja, mulai dari bayi, anak-anak, hingga orang dewasa. Virus corona ini bisa menyebabkan ganguan ringan pada sistem pernapasan, infeksi paru-paru yang berat, hingga kematian.

Hal tersebut membuat Indonesia menetapkan kebijakan untuk memberlakukan lockdown dalam rangka mencegah penyebaran virus. Beberapa pemerintah daerah memutuskan menerapkan kebijakan untuk meliburkan siswa dan mulai menerapkan metode belajar dengan sistem daring (dalam jaringan) atau online. Sistem pembelajaran daring merupakan sistem pembelajaran tanpa tatap muka secara langsung antara guru dan siswa tetapi dilakukan melalui online menggunakan jaringan internet.

Pembelajaran online bukanlah hal yang mudah, tak sedikit para orang tua mengeluh kesulitan dalam membimbing anak-anak mereka menyelesaikan tugas. Berbagai survey yang dilakukan menunjukan bahwa mayoritas pelajar yang melaksanakan sistem belajar online sejak pertengahan Maret lalu, menyatakan jenuh dan bosan dengan sistem belajar yang sedang dijalani.

Survey di atas mengindikasikan bahwa guru dituntut lebih kreatif dalam melaksanakan pembelajaran daring. Hal ini dapat dilakukan dengan mendesain strategi dan media pembelajaran kreatif. Game pembelajaran interaktif dapat menjadi salah satu solusi menjadikan pembelajaran lebih hidup.

Berdasarkan uraian di atas, penulis tertarik untuk melakukan pengabdian kepada guru tentang Pelatihan Pembuatan Game Interaktif dalam Pembelajaran Daring. Dengan adanya pelatihan ini, guru/ pengajar yang mengikuti pelatihan nanti dapat menerapkan game interaktif pembelajaran di kelas onlinenya. Akhirnya semoga siswa dapat menikmati proses belajar daring tanpa jenuh dan bosan, dan mendapatkan hasil belajar yang memuaskan walaupun dengan kondisi terbatas. 


\section{BAHAN DAN METODE}

Tidak banyak peralatan yang digunakan dalam pelatihan ini. Peralatan yang utama yakni terkait dengan pembelajran online berupa laptop yang terhubung dengan internet.

Materi pelatihan yang disampaikan meliputi: 1) Pentingnya pembelajaran daring yang menyenangkan, dan 2) Pembuatan game interaktif dalam pembelajaran menggunakan aplikasi Quizizz. Sementara untuk produk pelatihan berupa pembuatan konsep pembelajaran online yang diintegrasikan dengan aplikasi Quizizz disesuaikan dengan mata pelajaran yang diampu. (Materi dan produk peserta terlampir)

Ada beberapa metode yang digunakan dalam pelatihan pembuatan game interaktif ini. Metode-metode tersebut adalah:

1. Metode Ceramah

Metode ceramah dipilih untuk memberikan penjelasan tentang pentingnya pembelajran yang menyenangkan dan memotivasi guru-guru untuk melek internet.

2. Metode Tanya Jawab

Metode tanya jawab sangat penting bagi para peserta pelatihan, baik di saat menerima penjelasan tentang teori pelatihan serta saat mempraktekkannya.

3. Metode Simulasi

Metode simulasi ini sangat penting dilakukan kepada para peserta pelatihan untuk memberikan kesempatan mempraktekkan materi pelatihan yang diperoleh. Harapannya, peserta pelatihan akan benar-benar menguasai materi pelatihan yang diberikan. Selain itu, juga metode simulasi memungkinkan untuk mengetahui tingkat kemampuan guruguru dalam menerapkan hasil pelatihan.

4. Metode Penugasan

Metode penugasan merupakan kegiatan tahap akhir untuk mengetahui hasil pelatihan. Para peserta pelatihan membuat produk berupa pembuatan quis online dengan menggunakan aplikasi Quizizz.

\section{HASIL DAN PEMBAHASAN}

\section{Pelaksanaan/Hasil Pengabdian}

Workshop Pembelajaran Daring Menggunakan Quizizz diikuti oleh 60 orang peserta (guru) yang berada di kecamatan Malangbong. Latar belakang peserta kegiatan mayoritas adalah guru SD,SMP dan SMA/SMK. Berikut adalah tapan pelatihan yang dilakukan: 
1. Tahap Persiapan

Tahap persiapan yang dilakukan meliputi:

a. Survey tentang kendala-kendala yang dialami guru dalam pembelajaran online

b. Penyusunan bahan/materi pelatihan pembuatan game interaktif dalam pembelajaran daring.

c. Persiapan sarana dan prasarana (Aula untuk pertemuan offline dan Aplikasi Zoom untuk pertemuan online)

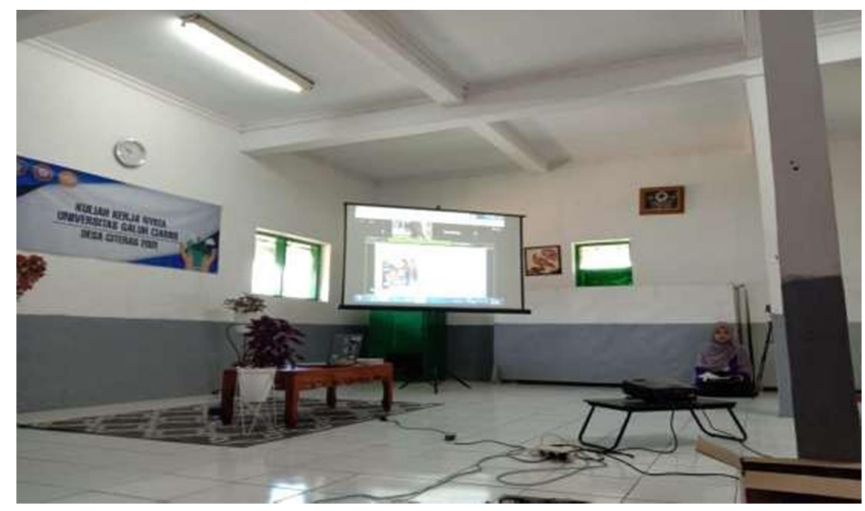

Gambar 1 Persiapan Pelaksanaan

2. Tahap Pelaksanaan Pelatihan

Pelaksanaan dilaksanakan pada hari Senin, 22 Februari 2021. Pelatihan ini dilaksanakan secara offline dan juga online. Pelaksanaan offline dilaksanaan di Kompleks Madrasah Aula Nurul Bayyan - Citeras Malangbong-Garut.

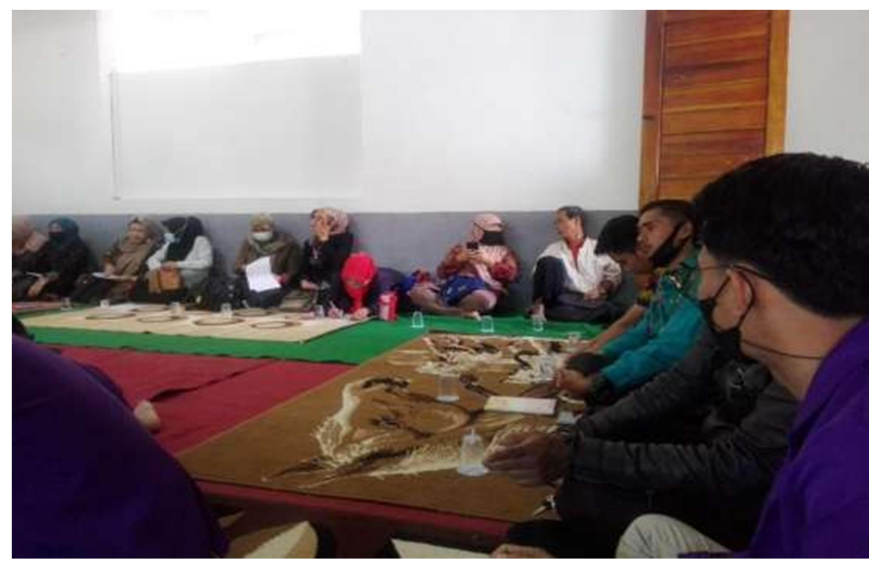

Gambar 2. Pelaksanaan secara offline

Pelaksanaan tersebut disiarkan langsung menggunakan aplikasi Zoom meeting. Sehingga peserta yang tidak bisa datang ke Aula Nurul Bayyan dapat mengikuti secara online. Dalam tahap pelaksanaan, sesi pertama pelatihan menitikberatkan pada pemberian penjelasan mengenai pentingnya pembelajaran daring yang interaktif dan 
variatif. Pada tahap awal ini, peserta dibuka wawasan terkait jenis-jenis ruang belajar yang dapat digunakan, sehingga tidak terfokus hanya menggunakan satu rung belajar.

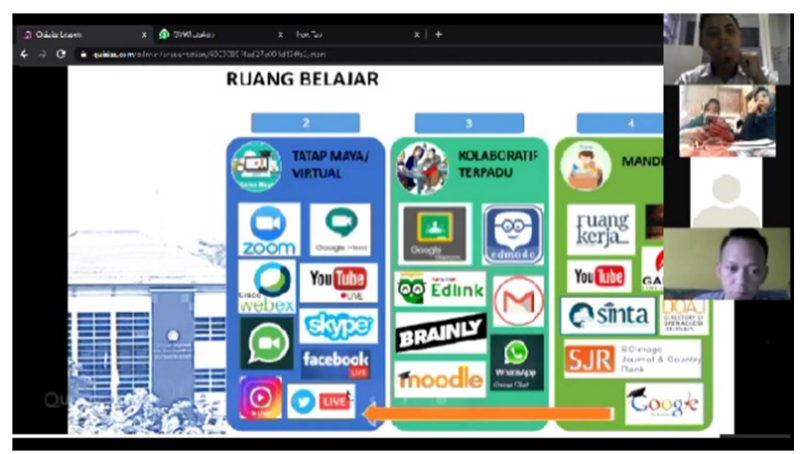

Gambar 3. Jenis-jenis ruang belajar

Selain itu, dikenalkan juga beberapa aplikasi quis yang dapat diintegrasikan dalam pembelajaran daring. Aplikasi tersebut diantaranya Quizizz, Slido, Kahoot, dsb.

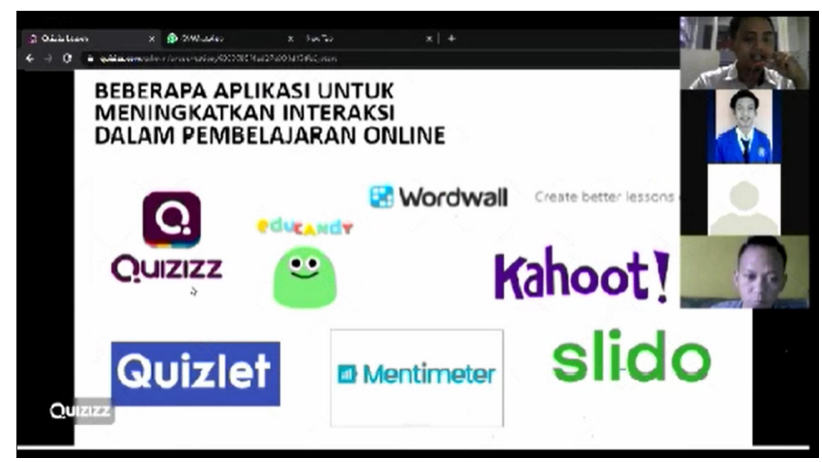

Gambar 4. Jenis-jenis aplikasi quis yang dapat digunakan dalam pembelajaran online

Kedua, sesi pelatihan menitikberatkan pada keterampilan membuat dan menyisipkan permainan interaktif dalam pembelajaran daring. Pelatihan keterampilan ini dilakukan dengan teknik simulasi agar guru-guru mendapatkan pengalaman langsung.

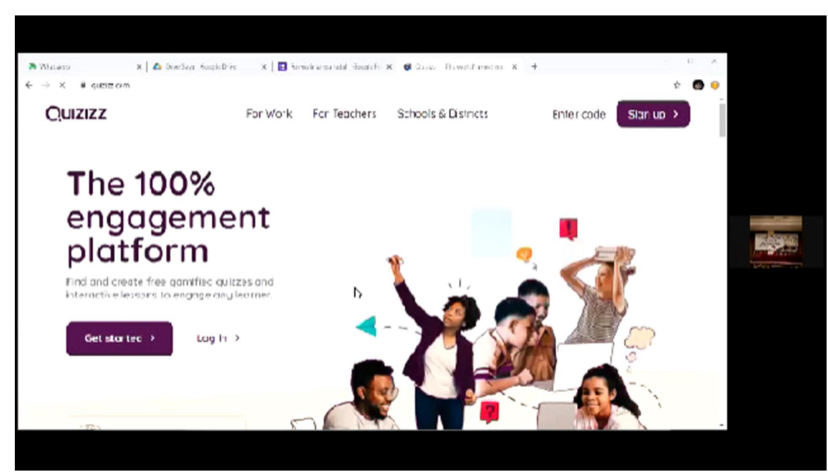

Gambar 5. Tampilan awal aplikasi Quizizz

Sesi terakhir, pembuatan produk oleh peserta dan pengumpulan produk. Dalam sesi ini, peserta selain diberikan paparan terkait tahapan-tahapan pembuatan, peserta juga 
dipandu secara khusus melalui grup WA. Di grup itu juga peserta membagikan hasil kreasinya dan diuji coba oleh peserta lain. Berikut beberapa contoh tugas peserta.

1. Game Pembelajran Bahasa Inggris

Link permainan:

https:/quizizz.com/join/quiz/600673ecd8958f001c131360/start?studentShare=true

Peserta mencoba membuat permainan pembelajran berkaitan dengan materi mengenal kosa kata hobi dalam bahasa inggris.

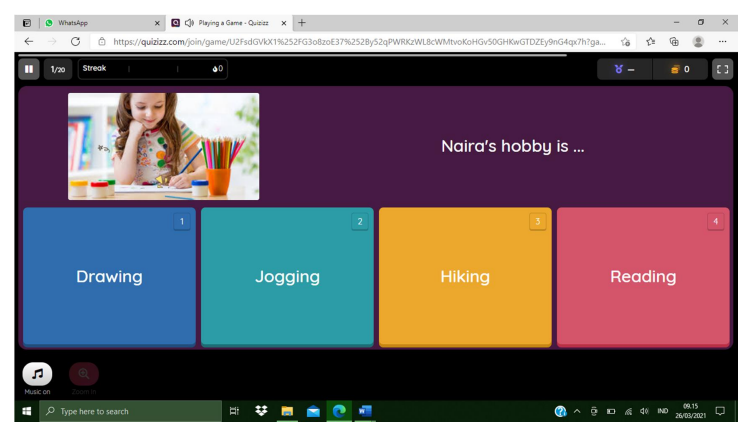

Gambar 6. Tampilan game pembelajaran karya peserta

2. Game Pembelajaran Agama Islam

Link permainan:

https:/quizizz.com/join/quiz/600673ecd8958f001c131360/start?studentShare=true

Peserta mencoba membuat permainan pembelajran berkaitan dengan materi tajwid.

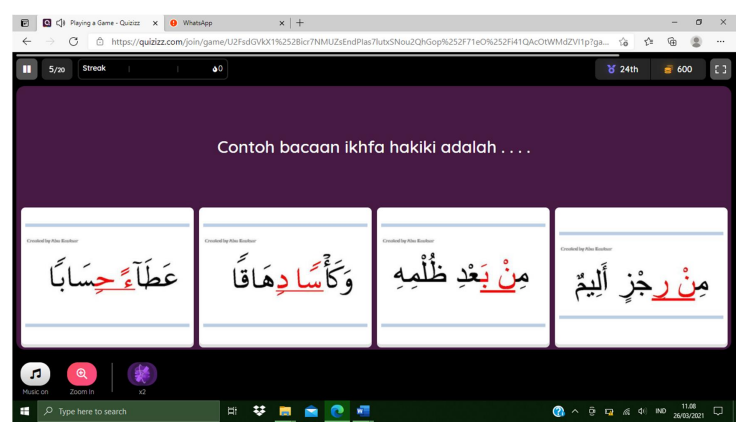

\section{Gambar 7. Tampilan game pembelajaran karya peserta}

Kegiatan workshop dilaksanakan selama 2 hari dengan 1 hari pemaparan materi dan praktek dan 1 hari lagi untuk membuat produk. Materi yang disampaikan dalam workshop berkaitan dengan pembelajaran dan teknis cara menggunakan quizizz. Berikut gambaran materi kegiatan workshop. 
Tabel 1. Kegiatan Workshop

\begin{tabular}{cll}
\hline NO & \multicolumn{1}{c}{ MATERI } & \multicolumn{1}{c}{ KETERANGAN } \\
\hline 1. & Persiapan & Paparan \\
& Pemaparan Kegiatan & \\
\hline 2. & Kegiatan Inti & Paparan dan dDiskusi \\
& Peningkatan Kualitas Pembelajaran Daring & Paparan,diskusi dan tugas mandiri \\
& Pembelajaran Daring menggunakan Qizizz & Diskusi dan tugas mandiri \\
& Membuat Produk Quizizz & \\
\hline 3. & Penutup & Evaluasi kegiatan \\
& Postest/Kuesioner & \\
\hline
\end{tabular}

Melalui kegiatan workshop pembelajaran daring ini peserta mendapatkan banyak manfaat anatara lain:

a. Peningkatan Kualitas Pembelajaran Daring

Kualitas pembelajaran daring sangat penting karena akan menentukan sejauh mana materi yang disampaikan guru akan terserap oleh siswa. Semakin berkualitas pembelajaran daring, semakin baik pula hasil yang akan didapatkan oleh siswa. Peningkatan kualitas pembelajaran daring dapat dilakukan dengan menentukan jenis dan ruang pembelajaran yang tepat untuk siswa. Selain itu, teknik, media dan model pembelajaran juga sangat menentukan keberhasilan pembelajaran.

Melalui workshop pembelajaran daring ini guru diberikan kiat dan cara bagaimana menentukan ruang pembelajaran serta media pembelajaran yang inovatif serta menyenangkan bagi siswa. Selain itu, guru juga diberikan pemahaman terkait pembelajaran daring.

b. Pembelajaran Daring Menggunakan Qizizz

Melalui materi pembelajaran daring menggunakan quizizz peserta workshop diberikan pelatihan dan cara menggunakan aplikasi quizizz untuk pembelajaran. Peserta diberikan pemaparan materi terlebih dahulu kemudian mempraktekkan (simulasi) cara pengoperasian quizizz. Melalui aplikasi quizizz peserta diberikan banyak pilihan bentuk soal yang akan di berikan kepada siswa. Selain itu, siswa juga akan merasa senang karena ada tantangan dalam pengerjaannya karena siswa akan langsung challenge dengan peserta didik lain dalam pengerjaannya.

c. Membuat Produk Quizizz

Kegiatan membuat produk quizizz merupakan tuntutan dari kegiatan workshop pembelajaran daring ini sebagai bentuk evaluasi keberhasilan workshop. Peserta juga diberikan solusi terkait permasalahan dalam pengerjaan produknya. Hal ini dilakukan 
agar semua peserta workshop dapat menggunakan aplikasi quizizz dalam kegiatan pembelajarannya.

\section{KESIMPULAN DAN SARAN}

Kegiatan “Workshop Pembelajaran daring Menggunakan Quizizz” yang diikuti oleh 60 orang guru di wilayah Kecamatan Malangbong berjalan dengan baik dengan hasil semua guru dapat mengopreasikan aplikasi quizizz dalam proses pembelajaran. Kegiatan workshop berjalan dengan lancar tanpa hambatan yang berarti.

Peningkatan kualitas pendidikan akan sejalan dengan kualitas pendidik. Untuk itu harus terus ditingkatkan kemampuan guru agar kualitas pendidikan menjadi lebih baik. Peningkatan kualitas pendidik dapat dilakukan dengan kegiatan pelatihan, workshop dll.

\section{DAFTAR PUSTAKA}

Ifijeh, G., Osinulu, I., Esse, U., Adewole-Odeshi, E., Fagbohun, M., 2015. Assessing ELearning Tools in an Academic Environment: A Study of Availability and Use among Undergraduate Students in a Nigerian University. Int. J. Progress. Educ. 11, $76-87$.

Harsasi, M., 2015. The use of open educational resources in online-learning: A Study of Students' Perception. Turk. Online J. Distance Educ. TOJDE 16, 74-87.

Komendangi, 2016. Analisis dan Perancangan Aplikasi E-learning berbasis Learning Manajemen Sistem (LMS) Moodle di Program Study Teknik Pertanian Universitas Sam Ratulangi. Manado: Universitas Sam Ratulangi

Misnawati. 2016. Hubungan Antara Kecerdasan Emosi dengan Kecanduan Game Online pada Siswa-siswi Di SMP YPS (Yayasan Pendidikan samarinda). Ejournal.Psikologi.Fisip-unmul.ac.id, 4 (2): 312-329.

Sagala, Syaiful., (2011), Konsep dan Makna Pembelajaran, Bandung: Alfabeta.

Undang-Undang No. 20 Tahun 2003

Young, K. S and Abreu, C.N de (Eds). 2011. Internet Addiction: A Handbook and Guide to Evaluation and Treatment. Hoboken, NJ: John Wiley \& Sons. 